\title{
THE TELEGRAPH INDUSTRY: MONOPOLY OR COMPETITION
}

THE domestic wire telegraph industry is a very nearly perfect example of duopoly in an essential public service. ${ }^{1}$ Wire record communication is, however, only one of several available services, and, year by year, the telegraph carriers yield to their competitors. a greater percentage of the tutal traffic. The Government-subsidized air mail now carries almost five percent of all intercity communications business..$^{2}$ Point-to-point radio telegraphy, whose development is limited by the small number of allocable frequencies, undercuts present telegraph rates by fifty percent, and has expanded rapidly in the past few years. ${ }^{3}$ The Bell System offers not only long-distance telephone rates in many instances lower than comparable telegraph rates, but also private telegraph facilities to large industrial customers in addition to its teletypewriter exchange service. The telegraph companies, which sixty years ago enjoyed a monopoly of rapid long-distance communications, and shared the traffic equally with the Bell System at the time of the first Vorld War, now control only a fifth of all the traffic.

Until the depression of 1929 , however, the rapid growth of the telephone company did not prevent the telegraph systems from earning greater operating revenues with each year, maintaining consistently high profits, and declaring generous dividends. But between 1929 and 1931 telegraph reventes were cut almost in half, and subsequent gains have fallen far short of reaching the 1929 level - although competing communications services reported 1940 revenues at an all-time high.5

Neither of the major telegraph carriers was prepared to absorb this drastic cut in revenues. Postal Telegraph had in 1927 undertaken an anlbitious program of expansion, ${ }^{6}$ and the depression caught it in a vulnerable position. By 1935 it had been forced into reorganization under Section 77D of the Bankruptcy Act. ${ }^{\top}$ Western Union weathered the storm by means of wage

1. The Western Union Telegraph Company and Postal Telegraph, Ince, divide the business on a ratio of approximately four-fifths to one-fifth. See Hcarinys lefore a sulcommittee of the Committic on Interstate Commerce un S. Res. 95, 77th Cong., 1st Sess. (1941) (hereafter cited as Hearings, 14f1) Pt. II, p. 2fo (table 12). A half-dozen small systems, serving special purposes, do a fraction of a percent of the total business. See iil. Pt. II, p. 239 (table 1).

2. See id. Pt. II, p. 243 (table 7).

3. This service is now offered by the Mackay System and by RC.l Communications, but on a very limited scale: only about a dozen wi the cuuntry's largest cities are currently linked by radiotelegraph circuits. Ste il. Pt. I, 111. 211-23.

4. See id. Pt. II, p. 243 (table 7).

5. See $i$ bid.

6. See id. Pt. I, p. 14.

7. The plan of reorganization was contirmed June $23,193 \%$. Befure the reorganization Postal had been a part of the complex system of holding and operating companies 
reductions, ${ }^{8}$ wholesale firing, speed-ups, and cuts in depreciation and maintenance charges. ${ }^{9}$ In spite of all expedients, however, Western Union announced a deficit in 1932, and dividends, which had been declared annually until 1930 at the rate of $\$ 8.00$ per share, were passed in 1933 and 1934 . The company was able to pay small dividends of irregular amounts during the next three years, suspended payments again in 1938 and 1939, and, with the help of war-time revenues, was able to pay a small dividenct in $1940 . .^{10}$

$\Lambda$ the present time revenues are increasing ${ }^{11}$ and both systems maly be expected to make a good showing during the next few years. ${ }^{12}$ But when the wartime demand for communications service has passed, and in the absence of governmental intervention, the entire industry might well be driven to the wall by the destructive competition to which it is and increasingly will be subject.

But some form of governmental action seems inevitable: the cost of preserving a dying industry is high, yet in this case it is less than the cost of allowing it to be destroyed. Over sixty thousand workers are employed by Western Union and Postal $;^{\mathbf{1 3}}$ the War and Navy Departments consicler their facilities for wire record communication essential to the national

headed by the International Telephone and Telegraph Company. In 1939 separate corporations were set up to operate the land lines and the radio-cable system. For the details of the plan, see MLoody's Public Utilities (1939) 948-49.

8. Successive cuts of $10 \%$ each were imposed in 1931 and 1932. On Western Union's labor practices during the depression, see testimony of Mr. Selly and of other representatives of the American Communications Association (CIO), Hearings (1941) Pt. I, p. 127 et seq. The company's labor policy through 1939 is reviewed in detail in Western Union Telegraph Co., Inc., 17 N. L. R. B. 34 (1939) (ordering disestablishment of the Association of Western Union Employees as a company union), aff'd. Western Union Telegraph Co. v. N. L. R. B., 113 F. (2d) 992 (C. C. A. 2d, 1940).

9. The charges made were so inadequate that it was necessary in 1937 to transfer $\$ 38,000,000$ from surplus to depreciation "in partial adjustment of improper accounting . . . aver a long period of years." Report of the Federal Communications Commission on the Domestic Telegraph Industry (December, 1939), reprinted Hlearings (1941) Pt. II, p. 394, 402.

10. See Hearings (1941) Pt. II, p. 241 (table 4).

11. The increase is less than might be expected, since the rates for Government mes sages are fixed annually by the Government itself at a fraction of the commercial ratc. This is done pursuant to a provision of the Post Roads Act of 1866, 14 SrNr. 221 ; the power is now exercised by the Federal Communications Commission under $\$ 601$ (b) of the Communications Act of 1934, 48 STat. 1104, 47 U.S.C. $\$ 601$ (b) (1940). These rates, which had been fixed for many years at $40 \%$ of the commercial rate [see $1 \mathrm{~F}$. C. C. 102 (1935), 4 F.C.C. 56 (1937)] were raised to $60 \%$ in 1939 after repeated solicitations by the carriers. See IVestern UNion, ANNunl Repokt (1939) 2.

12. Postal Telegraph has, however, operated at a deficit from its rcorganization until well into 1941. An RFC loan of $\$ 5,000,000$, which it had secured for working cap* ital after reorganization in 1940 , was largely exhausted by the middle of 1941 . Sce state. ment of FCC Chairman Fly, Hearings (1941) Pt. I, p. 14.

13. As of December 31, 1940, 62,062. See id. Pt. II, p. 274 (table L-1). 
defense $;^{14}$ the telegraph companies still furnish the only service of its type available to the general public ${ }^{15}$ finally, the physical plants represent an investment of nearly half a billion dollars. ${ }^{16}$ Various possible solutions suggest themselves: the establishment of a wire communications monopoly by allowing the Bell System to take over the telegraph companies; merger of Western Union and Postal under conditions imposed by the Government, which would somehow guarantee the surviving company the right to continue profitable operations; or outright Government ownership and uperation of the telegraph industry, either as part of a comprehensive plan for taking over all communications or as an expedient to continue an essential public service no longer profitable in private hands.

There is little likelihood that either the public or Congress would approve a complete monopoly under the Bell System. And the only impetus to Government ownership in the past twenty years has come from sporadic and ineffectual resolutions in Congress proposing the postalization of the whole communication system. ${ }^{17}$ Although the war period may induce further consideration of this proposal, to date the merger solution alone has received thorough examination. Schemes for combining the two companies have been current on the industrial scene for more than twenty years. ${ }^{18} A$ bondholders' committee during Postal's reorganization proposed consolidation with Western Union. ${ }^{19}$ The Federal Communications Commission in 1939 submitted a report, prepared pursuant to a resolution of the 76th Congress, and recommended legislation allowing merger. ${ }^{20}$ The Senate Committee on Interstate Commerce, after hearings held in May 1941, substantially adopted the Commission's recommendations in its report to the Senate.21

The investigation, hearings, and reports referred to, none of them elaborately carried out, represent the first attempts by the Federal Government to gather detailed information on the structure and to make comprehensive proposals for the future regulation of an industry which has been, nominally, under federal supervision for thirty years. The legislative record of a slowly and tardily developed national communications policy is curlously barren and casual, and nowhere more so than with respect to the problems of wire telegraphy.

14. See statements of Rear Admiral Hooper and Major General Mauborgne, id. Pt. I, pp. 61, 64.

15. The Bell System offers to large industrial users permanently installed telegraph facilities, with service over the telephone lines.

16. See Hearings (1941) Pt. II, pp. 239, 241 (tables 2 and 5).

17. See H. R. 14169, 67th Cong., 4th Sess. (1923), H. R. 9275, 69th Cong., lst Sess. (1925-26), H. R. 9244, 68th Cong., 1st Sess. (1923-24), H. R. 11944, 69th Cong., 1st Sess. (1925-26), H. R. 9845, 70th Cong., 1st Sess. (1927-28).

18. See H. R. Rep. No. 1273, 73d Cong., 2d Sess., (1934) Pt. III, No. 1, pp. s, xi.

19. See Moony's Public Utulities (1938) 1311.

20. Reprinted in Hearings (1941), Pt. II, pp. 394-449.

21. SeN. Rep. on S. Res. 95, 77th Cong., 1st Sess. (1941). 
No federal regulation of interstate wire communications was attempted until 1910, when jurisdiction over the rates and charges of telephone and telegraph companies was vested in the Interstate Commerce Commission. ${ }^{2}$ The Transportation Act of 1920 , a comprehensive revision of the Interstate Commerce Act after the period of wartime control of transportation and communications, reaffirmed the Commission's authority, ${ }^{23}$ and in 1921 it was given power to approve consolidations, mergers or leases among telephonc companies. ${ }^{24}$

But the authority granted the ICC in these successive enactments remained largely a paper authority. ${ }^{25}$ Although the wire companies were atthorized to file rate schedules, the Commission was not empowered to require that they be filed, ${ }^{26}$ nor to initiate investigations or order revisions except on complaint. The practice of proceeding only after a complaint had been filed by an aggrieved party had worked well enough where railroad freight charges were involved; the considerable amounts in question automatically produced complaints where overcharges or unlawful discriminations were suspected. On the other hand, the relatively small interest of any individual user of communications services was not ordinarily conducive to the initiation of formal proceedings before the Commission with the hope of gaining a rebate. ${ }^{27}$

Nevertheless, the Commission made some show of exercising its atthority over wire communications. A tuniform system of accounts was prescribed in $1913^{28}$ which remained in force until after 1934. There was some consideration of telephone depreciation charges in 1926 and again in 1931, but

22. Act of June 18, 1910, \$7, 36 Srat. 539, 544. This was the Mann-Elkins Act, which set up the ill-fated Commerce Court and considerably extended the power of the ICC over the railroads; inclusion of telephone and telegraph carriers within the Commission's jurisdiction was one of the less significant amendments to the Act and passed without much consideration. See Sharfina, The Interstate Commerce Commission (1931) Pt. I, p. 52.

23. 41 Stat. 456. Section 400(2) (b) excluded from the Commission's juriseliction intrastate wire and wireless communications.

24. Act of June 10, 1921, 42 Stat. 27.

25. See H. R. Rer. No. 1273, 73d Cong., 2d Sess. (1934) (Preliminary Report on Conmunications Companies) xvi; remarks of Representative Rayburu and Scnator Dill in the debates on the Communications Act of 1934, 78 CoNa. Rec. 8822, 10315 (1934); Wheat, The Regulation of Interstatc Telcphonc Ratcs (1938) 51 Hukv. L. Rkv. 846, 847; Sharfani, op. cit. supra note 22, Pt. II, p. 117.

26. The Commission repeatedly urged the modification of the statute so as to repuite the wiro carriers to file rate schedules. ANNus Rep. ICC $(1911,1912,1913,1915)$. See Sharfinan, op. cit. supra note 22, Pt. II, p. 108.

27. See Wheat, loc. cit. supra note 25 .

28. See AnNual Rep. ICC (1913). A revised set of accounting rules was thade effective in 1933. After the Federal Communications Commission assuned jurisdiction in 1934, a new Uniform System of Accounts was issued to take effect in 1936. 'The Connmission's system of accounts was upheld by the courts. American Tel. \& Tcl. Co. v. United States, 299 U. S. 232 (1936). 
no final order was ever issued.9. A valuation of the Western Union properties, begun in 1914, dragged on for twenty years and was still in tentative form when transferred to the Federal Communications Commission in 1934.50 Apart from these major efforts, a few scattered telephone cases and a slightly greater number of telegraph cases came before the ICC during the twentyfive years of its jurisdiction. ${ }^{31}$

The net result of regulation under the ICC may well have been to relieve the wire carriers of any effective governmental control in the public interest. It was held by the Supreme Court that the Mann-Elkins Act was an exclusive occupation of the field by the federal authority and prohibited any state action which might burden interstate commerce. ${ }^{32}$. 1 decade of inconclusive attempts by the states to regulate rates culminated in the holding that, as a condition precedent to state regulation, separation studies must be made allocating ratebase and operating costs as between intra- and interstate traffic. ${ }^{33}$ This decision wrote finis to any hope for effective state regulation of local telephone or telegraph rates. The result was that the general rate structure of the telegraph companies was left unregulated, unlitigated, and unchanged.

Between July 31, 1918, and August 1, 1919, all the wire cummunications facilities in the nation were under Government control and operation. A joint resolution of Congress, which became effective July 17, 1918, authurized the President "whenever he shall deem it necessary for the national security or defense . . . to take possession and assume control of any telegraph, telephone, marine cable or radio system . . . and to operate the same in such manner as may be needful or desirable for the duration of the war. . . ." ${ }^{34}$ This authority was exercised by an executive order dated July 22, which placed the Postmaster General in charge of the program and empowered him to perform the duties vested in him through the officers and directors of the various companies taken under federal cuntrol..$^{35}$ The Postmaster General created a Wire Control Board, cumposed of himself as chairman and three other Government officials, which was charged with administration, operation, and finances of the communications system. ${ }^{30}$ How-

29. Depreciation Charges of Telephone Companies, $11 \mathrm{~S}$ I. C. C. 295 (1920), 177 I. C. C. 351 (1931).

30. See 1 F. C. C. 6 (1934). Western Union, Anzual Reponts, passim.

31. See Sharfacin, op. cit. suira note 25, at 110 (collecting cases).

32. Postal Telegraph-Cable Co. v. Warren-Goodusin Lumber Co., 251 U. S. 27 (1919).

33. Smith v. Illinois Bell Telephone Co., $2 \$ 2$ U. S. 133 (1930). While more than $80 \%$ of telephone revenues arises from intrastate business, the great bulk of telegraph is interstate, and the permissible area of state action would be in any case greatly restricted.

34. 40 STAT. 904.

35. 40 Stat. 1807 .

36. The Postmaster General's orders and final reports to Congress are collected in a publication issued by the Post-Office Department, Governasest Costror asid Orras- 
ever, under an order of the Postmaster General issued August 1, 1918, it was provided that "until further notice, the telegraph and telephone companies shall continue operations in the ordinary course of business through regular channels." ${ }^{3 i}$ In legal effect this meant that the corporations became agents of the Government for the operation of the various systems, and that the Government assumed the liabilities and responsibilities accruing in the course of business. ${ }^{38}$ Later an Operating Board was set up composed of operating officials of the telegraph and telephone companies, which assumed control of operations on January 1, 1919, and continued in charge until shortly before the return of the properties to private hands..$^{30}$

The original joint resolution for wartime control of the companies was passed in terms of a broad grant of power to the President to be exercised at his discretion and the details of administration to be improvised at his pleasure. The only limitations upon the President's power were that Government control should not extend beyond the date of ratification of the peace treaties, that just compensation should be made to the companies, and that nothing in the resolution should be construed to limit the powers of the states in regard to taxation or police regulations. ${ }^{40}$ The form of the reso-

tion of Telegraph, Telephone and Makine Cable Systens (1921) (hereafter cited as Government Control). The Wire Control Board was created by Order No. 1744, July 23, 1918, Governament Control 61.

37. Order No. 1783 , id. at 62 .

38. Report of the Postmaster General on the supervision and operation of the telegraph, telephone and cable properties, S. Doc. No. 152, 66th Cong., 1st Sess. (1919). Government Control 9.

39. Order No. 2479, Dec. 13, 1918. Governament Control 74.

40. The legislative history of the joint resolution is confused. It was introduced into a weary Congress, intent on an early recess, and passed without hearings and almost without debate. The House limited itself to two hours discussion on the measure; the Senate devoted parts of two days. While the measure was before the House, a scriots strike threatened to tic up the Western Union system, and it is apparent from the debates that many members assumed that the resolution was intended to give the President power to intervene in case the strike was called. See 56 CoNG. Rec. 8717, 8718, 8729 (July 5, 1918). By the time the resolution reached the Senate floor, however, the strike threat had been clissipated, and Administration spokesmen presented the measure as a grant of power which the Executive should have in case of emergency, but which would probably not be exercised. See id. at 8971 (July 11th). In the House there had been only four dissenting votes; the Senate vote was 46 to 16. Sec id. at 8730, 9094. Sittce the President's proclamation assuming control included telephone as well as telegraph conpanies, threatened labor disputes can hardly be assigned as the reason for the decision to exercise the power. Furthermore, the cable systems, which would seem more intimately connected with national defense than the domestic wire systems, were not taken under Government control until November 2, 1918 (40 STAT. 1872) and were returned to private hands several months before the wire systems (Postanaster General's Order No. 3047, April 29, 1919; Governuent Control 53). It was charged in Congress that Postmaster General Burleson, who had gone on record as favoring Government ownership of communications [see Sex. Doc. No. 399, 63d Cong., 2d Sess. (1914)] was using the war as an excuse for the first step towards this objective. See 56 Cong. Rec. 8717 
lution was borrowed largely from an Act of 1916 which had given the President power to assume control of the railroads for the duration of the emergency. ${ }^{41}$ When the authority given the President to control the railroads was exercised, ${ }^{42}$ Congress had promptly passed legislation providing in some detail for their administration. ${ }^{43}$ And in passing the communications resolution, Congress apparently assumed that similar detailed legislation would be introduced in the event the President determined to exercise the authority granted.44 But although both telephone and telegraph soon passed under Government control, no further action was taken. ${ }^{45}$ And since the Congressional resolution failed to specify the conditions under which the Government was to assume control, the execution of all of the details was left to the Postmaster General, who negotiated and approved contracts with the various companies. The contract with T'estern Union provided, among other things, that the Government would continue service at a standard of efficiency relatively equal to that of the past, would maintain the property in a state of repair relatively equal to that existing at the date Government control began, that depreciation charges would be made at stated amounts and provision made for the amortization of intangible capital and rights of way, and that the Company should at all reasonable times have the right to inspret property and books. The Government further undertook to pay the company annually during federal control the interest on all bonds and obligations outstanding on July 31, 1918, plus approximately $\$ \$, 000,000$, and to save the company harmless from all liabilities growing out of claims accruing during the same period. All patents owned by the company were to be used by the Government free of charge. Dividends paid by the company were not to exceed $7 \%$ annually. ${ }^{40}$

(1918). The charge was renewed in the dehates on repealing the joint recolution the following year. See 58 Cong. Rec. 1347. See further, Hearings before Committce on Interstate Connmerce on S. 120, 66th Cong., 1st Sess. (1919).

41. 39 Stat. $619,645$.

42. 40 Stat. 1733 (1917).

43. Federal Control Act, 40 Stat. 451 (1918).

44. See 56 Coxig. Rec. 8729 (191S).

45. An anti-sabotage act was passed, designed to protect the properties of the companies and to maintain the secrecy of messages during the period of government control. Act of Oct. 29, 1918, 40 Stat. 1017. War revenue taxes were levied on telegraph and telephone messages. 40 STAT. 315, 1102 (191S). Among the omissions which later led to some confusion was the failure of Congress to provide who should be sued on tort claims arising during the period of government control. See Poston v. Western Union Telegraph Co., 256 U. S. 662 (1921) (ordering the complaint dismissed). "If Congress has omitted to provide adequately for the protection of rights of the public, Congress alone can provide the remedy." Id. at 667.

46. See Western Union, AnNual Refort (1919) 12-25. No contract was negotiated with Postal, and for a time litigation over the compensation offered by the Government was expected. See Governarent Control 17-18. Suit was filed by the Government against Postal (see id. at 37) but a settlement was reached outside the courts. In general the communications companies were surprised and pleased at the highly favor- 
Compensation awarded the companies under the contracts and by settlements extraneous to the contracts exceeded by some twelve and a half million dollars the revenues obtained by the Government from operation of the properties. ${ }^{47}$ In an attempt to reduce the size of the growing deficit, the Postmaster General proclaimed increased rates for both telephone and telegraph service, intrastate as well as interstate. ${ }^{48}$ These rate increases, designerl as temporary expedients to raise revenues in a time of high labor and material costs and to enable the Government to meet the heavy burden of just compensation, proved to be the most enduring feature of the period of fecleral control. The telegraph companies continued the rates in interstate traffic and were able to have them approved by all but one of the state commissions for intrastate service. ${ }^{49}$ Until this unexpected windfall of Government sponsored rate increases, the structure of telegraph rates had remained fixed since 1887, except for the introduction of lower charges for various types of deferred service. ${ }^{.0}$

The wartime operation of the communications system might well have been an initial step towards a reasoned national communications policy. But in fact it was merely a brief, unrelated hiatus in the haphazard accumulation of ad hoc legislation made to substitute for policy. A few hours of cursory debate sufficed to hand over to the Executive all the country's facilities for rapid communication. Brief hearings followed by even less - as well as less

able terms they were able to obtain. See Danielian, AT\&T (1939) c. XI. The Western Union Co. publicly praised the government for a policy "constructive and eminently fair to the property." ANNUAL RePORT (1919) 5.

47. See Government Contror. 38. This governmental "extravagance" and "inefficiency" provoked violent criticism in Congress on the occasions of repealing the origital government control resolution which was effected by Act of July 11, 1919, (41 STAT. 157) and of appropriating funds to meet the federal deficit, Third Deficiency Appropriations Act of 1920 (41 Stat. 1015, 1021). See 58 Conc. Rec. 919 (1919).

48. Telephone rates were increased by OrDer No. 2495, Dec. 13, 1918 (GovernMent Control 75); telegraph rates by ORder No. 2940, Mar. 29, 1919 (id. at 86). The in. crease in telegraph rates was $20 \%$. Various state Public Utilities Commissions attempted to enjoin the intrastate increases, but the Postmaster General was upheld by the Stupreme Court, which, declaring that "the complete and undivided warpower of the United States is not disputable," concluded that federal power over all rates was exclusive, notwithstanding the statutory provision reserving the rights of the states. Northern Pacific Ry. v. North Dakota, 250 U. S. 135 (1919) (railroad rates); Dakota Central Telephone Co. v. South Dakota, 250 U. S. 163 (1919); Kansas v. Burleson, 250 U. S. 188 (1919); Burleson v. Dempcy et al., 250 U. S. 191 (1919); McLeod v. New England Telephone and Telegraph Co., 250 U. S. 195 (1919).

49. See Western Union, Annual Report (1920) 6. Postal, which at that time maintained offices only in the larger cities and thus secured the most profitable business, proposed to go back to the old rates for itself; but it was held that this would give it an unfair competitive advantage over Western Union, which, as a common carrier, was obligated to maintain service even where the volume of business did not make it profitable. See In re Western Union Telegraph Co., PUR 1920F, 370 (Nevada Public Service Commission).

50. See Western Union, Annual Report (1920) 15. 
relevant - debate marked the end of the experiment. Telephone and telegraph followed the country back to normalcy to prosper unregulated in the twilight zone which lay between intrastate and interstate commerce. Discovery of the confused pattern of interrelated and competing industries in this case utilities rendering an essential national service which must be regulated nationally or not at all - did not fit the needs of post-war boom. The Postmaster General's report to Congress shows that evils were then clearly foreseeable, which, in the absence of any action by Congress, were left to mature through the succeeding decades.

The absence of any comprehensive communications policy has heen most frequently expressed in anti-monopoly riders attached to the various enactments which have been the piecemeal response to a problem more and more urgently demanding an integrated solution. Meanwhile the communications services, obedient to the logic of circumstance, have themselves moved toward unified operation, cooperation, or at the least gentlemen's agreements. To Congress the abandonment of the competitive formula may have seemed a regrettable consequence of the depression. But for a half-century the industry has moved warily on the periphery of the anti-trust laws. ${ }^{.1}$

An exception to the Congressionally sponsored ideal of perfect competition among all types of communications, as well as within each separate branch of the industry, was made shortly after the World War. At that time telephone service was furnished not only by the Bell System but also by some eight thousand independents. On the initiative of the independents, ${ }^{\text {t2 }}$ many of whom were close to bankruptcy, a bill was passed which authorized consolidations, mergers, or longterm leases among competing telephone carriers upon application to the Interstate Commerce Commission and finding and certification by the Commission that the merger would be in the public interest. $^{53}$ But at no time in the legislative proceedings was consolidation among the telegraph companies mentioned, although that possibility had been brought to the attention of Congress in the recently submitted report by the Postmaster General on the federal operation of the communications system.

51. Western Union and the American Telephone and Telegraph Company were under a unified control from 1909 to 1912. The agrressive anti-trust policy of the first Wilson administration broke up this near monopoly in electrical communications, and, by the so-called Kingsbury Commitment, AT\&T agreed in 1913 to dispose of its Western Union holdings. See Proposed Rerort on the Tenephorte Investicntro:: (1938) 155-56; Danielan, op. cit. supra note 46 at 74ff.

52. See 61 Cong. REC 1982 (1921).

53. 42 Stat. 27 (1921). The policy of consolidating the companies had been begun during the period of Government control, when 34 consolidations were approved. See Governarent Control 11. The companies were unwilling to continue the policy without express governmental sanction, in view of conflicting decisions in the federal courts. United States Telephone Co. v. Central Union Tel. Co., 202 Fed. 60 (C. C. A. Gth, 1913); Pacific Tel. \& Tel. Co. v. Anderson, 196 Fed. 699 (E. D. Wash. 1912). Between 1921 and 1934, 287 consolidations were approved. See Sharfanar, The Interstate CossaterCe CoManission (1935) Pt. III A, pp. 27-2S, Pt. IV (1937) 226. 
The formula of strict competition was not abandoned, however, except in the instance of the telephone consolidations. The Radio Act of $1927^{64}$ codified the policy, theretofore carried out by the Department of Justice under the anti-trust laws, of segregating the communications system into isolated compartments. Under Section 17 of the Act any approach to joint control of radio and telephone, telegraph or cable systems was made illegal. ${ }^{\text {t5 }}$ The policy of this section was continued by Section 314 of the Commtnications Act of $1934,{ }^{56}$ which vested in the Federal Communications Commission the control over wire and wireless carriers which the gradual accretion of legislation had deposited with various other agencies of Government. ${ }^{\text {.7 }}$

Within the narrow limits prescribed by repeated Congressional and Executive action the communications companies have nevertheless tended towards an informal cooperation. In 1931 Western Union and Postal, for example, in an attempt to meet competition from the Bell System's TWX service, combined to introduce a timed-wire service through coordination of their printer services and publication of a common directory of the timed-wire customers of both companies. Western Union concluded successive contracts in 1928, 1931 and 1934 with RCA Communications by which it became the collector and distributor of all RCA's transoceanic radio telegraph traffic except in the few large cities where RCA had established its own pick-11p and delivery service. ${ }^{58}$ Both Postal and Western Union negotiated contracts in many localities with the telephone companies, providing for transmission of messages over the telephone companies' lines. ${ }^{50}$ In 1928 Western Union and AT\&T agreed to combine facilities for the development of a photogram and telephotograph service and for the cross-licensing of certain patents. ${ }^{00}$

Although the ideal of pure competition to which successive Congresses had subscribed was thus somewhat tarnished, the sanctions imposed were effective in keeping alive a destructive and at times violent struggle for the division of new territory. Even the complicated pattern of bilateral agreements among the several companies reveals a balance of power policy of aiding the weak against the strong. The Bell System and General Electric fought to achieve near monopoly over the two great technical developments of the post-war period: radio broadcasting and sound motion pictures. ${ }^{01}$ AT\&T over many

54. 44 STAT. 1169,47 U. S. C. $\$ 81$ (1940).

55. "if . . . the purpose is and/or the effect . . . may be to substantially lessen competition or to restrain interstate or foreign commerce or unlawfully to create monopoly in any line of business."

56. 48 Stat. 1064 et seq., 47 U. S. C. $\$ 151$ et seq. (1940).

57. 48 STAT. 1101,47 U.S. C. $\$ \S 601,602$ (1940).

58. See Western Union, ANNuAl REports for the years mentioned.

59. See Moody's Public Umilities (1931 and following years). The validity of such contracts was upheld in In re Postal Telegraph-Cable Co., PUR 1933C, 124 (III. Public Service Commission).

60. See Western Union, Annual Report (1928) 7.

61. See Daniblian, AT\&T (1939) c. vii. 
years refused to accord local facilities to net-work radio programs carrici over Western Union wires. ${ }^{62}$ And after 1927 Western Union and Postal were engaged in bitter competition which, with the depression, finally drove the latter into reorganization.

The Communications Act of $1934^{63}$ established for the first time an agency with jurisdiction over all types of communications, and, while the new Commission was to some extent merely the latest repository of already granted powers, some of the previous legislative gaps were filled in for the purpost of allowing it to exercise a really effective regulation. ${ }^{\text {ot }}$ The Act gave the Commission comprehensive regulatory powers uver the communications systems as they had developed, as well as power to control future developments. It had, however, no authority to impose any changes nor, except in the matter of telephone consolidations, ${ }^{65}$ to relax the requirements of the antitrust laws. Problems within the industry, which, as far as the telegraph companies were concerned, had already become acute, were left for future solution.

This failure to deal with existing problems did not proceed from a lack of information, since the House investigating committee had prepared an elaborate and exhaustive report on the entire communications situation. ${ }^{63}$ The committee's final report on the proposed legislation concluded, however, by pointing out that "the bill now considered holds in abeyance the answers to some of these questions until such a time as further study and observation may make clear what Congress might reasonably expect from a given policy." 67

Although regulation of communications generally and of telegraph particularly by the Commission has been more effective and intelligent than anything accomplished by the agencies to which the Commission succeeded, administrative policy has nevertheless been limited by the considered decision of Congress to postpone any definitive solution. While repeatedly recommending that the telegraph companies be relieved of the burden of the antitrust laws, the Commission has, no doubt correctly, interpreted its Act as

62. See id. at 166 .

63. 48 Stat. 1064 et seq., 47 U.S. C. $\$ 151$ et seq. (1940).

64. The FCC received the power to require extension of service $[\$ 201(a)]$, to furbid discriminations and preferences $[\$ 202(a)]$, to require rate schedules to be filcd with it $[\$ 203]$, to proceed upon complaint or upon its own initiative $[\$ 204]$, to preserite just and reasonable maximum and minimum charges [\$205]. Interlocking directorates ar: forbidden except on approval of the FCC [\$212]; all contracts between carriers must be filed with the FCC [\$211], which may modify or ayoid certain classes of contracts [\$215]. The interest of the states is recognized by a provision allowing the FCC t.s call in representatives of the states affected in any froceeding and to constitute joint federal-state boards [\$ 410$]$.

65. See note 53 supra. This provision is continued in the Communieations Act of 1934.

66. H. R. REP. No. 1273, 73d Cong., 2d Sess. (1934).

67. Id. at $\cdot$ Pt. III, No. 1, p. xi. 
calling for the continuation of at least a limited competition. Orders pursuant to specific provisions of the Act issued, after hearings, forbidding most interlocking directorates. ${ }^{68}$ The use of telegraph franks as a means of granting rebates to favored customers was strictly regulated, and prosecutions were instituted to curb violations. ${ }^{60}$ On the other hand, the Commission has held more than once, and has been sustained by the courts, that competition is required by the Act only to the extent that it can be found to be in the public interest. ${ }^{70}$

Against this background of an industry admittedly driving towards failure and on this record of legislative caprice and delay, the Senate Committee on Interstate Commerce has undertaken to formulate the long postponed solution.

After hearings and study the Committee has recommended ${ }^{71}$ that Congress amend the Communications Act of 1934 to allow domestic telegraph carricrs to merge into one company and international telegraph carriers to merge into another, entirely separate and distinct from the first. ${ }^{72}$ The Committee urges legislation requiring that appropriate regulatory agencies see that the merged company or companies be set up with the simplest possible financial structure. Further recommendations include specific provision for the "fullest reasonable protection" of workers through a formula of dismissal pay and pension payments, the working out of the formula to be made a condition precedent to merger. The regulatory powers of the Communications Commission should be continued, with additional authority to make a fair and equitable distribution of traffic between the domestic and international carriers. Congress should consider modifying the existing law by which Government messages are carried at rates fixed by the Government. There should be, further, "specific proper safeguards for the interests of the using and general public and the industry as a whole."

68. 2 F. C. C. 741 (1935) ; 3 F. C. C. 691 (1936) ; 4 F. C. C. 709 (1937).

69. See Telegraph Division Order No. 7, 1 F. C. C. 78 (1935) ; 8 U. S. L. WEEk 672 (E. D. Penn. 1940).

70. Thus the Commission has denied an application for permission to establish a new radio telegraph circuit between the United States and Norway. Mackay Radio and Telegraph Company, Inc., 2 F. C. C. 592 (1936), aff'd sub nom. Mackay Radio and 'Telegraph Co. v. FCC, 97 F. (2d) 641 (App. D. C. 1938). It has also requtircd the discontintuance of a leased circuit between two cities when existing facilities were adequate. Mackay Radio and Telegraph Co., 26 PUR (N.s.) 289 (FCC, 1938).

71. See Sen. Rep. on S. Res. 95, 77th Cong., 1st Sess. (1941) 25.

72. The mergers are to be voluntary, and it is not suggested that they must be carried out simultaneously. Only once in the hearings was the idea of compulsory merger raised, and then it was promptly dropped with the remark that it "raised a lot of questions." See Hearings (1941), Pt. I, p. 104. A not insuperable barrier may be presented by such cases as ICC v. Oregon-Washington Ry. and Navigation Co., 288 U. S. 14 (1933). If, however, compulsory merger legislation were passed under the war power, presumably no constitutional question would be raised. See cases cited supra note 48 . This possibility was not, of course, under consideration at the time of the hearings. 
The ambiguous suggestion that safeguards for the industry be written into the legislation may refer to some of the Committee's "conclusions" which were not otherwise incorporated into its final recommendations. The Committee felt that the merged telegraph company, if it were still to be subject to the "overwhelming" competition of telephone, radio and airmail, would have little chance of profitable survival. The new company, therefore, should be protected against competition not only within the telegraph field, but from the other forms of communications as well. The suggestion was made that the Bell System's TWX service be incorporated in the new telegraph carrier through some sort of lease arrangement, which would allow the telegraph company to furnish the service over the circuits owned and now used by the telephone company. To put an end to the growing threat of cheaper service from radio telegraph, it was urged that this form of communication be abandoned except as a feeder for the international traffic carried by the radio companies. ${ }^{73}$ No suggestion was advanced in favor of curbing the airmail.

If the Committee's conclusions and recommendations should be written into law, Congress would be adopting a legislative policy containing many startling novelties. The scheme proposed goes far beyond the mere relawation of the anti-trust laws in favor of a distressed industry which technological advances have placed at a serious competitive disadvantage. Not only is monopoly to be allowed, but bulwarks against competition and threat of competition are to be provided. The presently insolvent and unprogressive segment of an industry is to receive the windfall of a share of the business now carried on by its more up-to-date rivals, and a perpetual injunction against the exploitation of a promising new technique which the donee of this largesse is unable to develop by its own resources. In order that the existing telegraph plant be not scrapped, the Committee is willing to talie the risk of freezing the inventive process at its present level in the improvement of point-to-point radio telegraphy, and explicitly favors malking this cheaper service unavailable to the general public. ${ }^{74}$

Only relatively small economies are expected to result from the merger. One of the basic difficulties of the telegraph situation is that the present system of land-lines represents to a considerable extent excess capacity which cannot be profitably employed under normal conditions, but which, since it cannot be quickly improvised in emergency periods when it is needed, nust nevertheless be maintained. ${ }^{75}$ At least during the war, and thereafter as

73. See SEN. Rep. on S. Res. 95, 77th Cong., 1st Sess. (1941) 20-21. These cunclusions are substantially in accord with the policies advocated by FCC Chairman Fly before the Committee. See Hearings (1941) Pt. I, p. 18-23.

74. Mr. Craven, a member of the FCC representing a minority view within the Conmission, criticized this proposal before the Committee See Hcarings (1941) Pt. I, p. 218 et seq.

75. Statement of Commissioner Craven, id. at 219. 
well if the opinion of the War and Navy departments prevails, ${ }^{76}$ there will be no elimination of duplicate transmission facilities, however little nceded. Moreover the existing plant of both companies is in large part far from new, and charges to depreciation and obsolescence, as well as the actual outof-pocket cash expense of repair and maintenance, may be expected to increasc sharply. ${ }^{77}$ Labor costs will be less in the long run, although the proposals for protection of displaced employees will make any immediate saving improbable. The most hopeful source of economy is the elimination of the offices now maintained by Western Union and Postal in most large citics, usually in ligh rent locations and frequently in the same block..$^{78}$ Whatever expense is. now incurred by each company in attracting business from the other will be saved, and there are some possibilities of economy in the mere fact of consolidation. If the merger should be carried through on the lines of a corporate reorganization, and the present bondholders awarded some form of unsecured participation, the heavy fixed charges now carried by Western Union could be cut down. ${ }^{70}$

In whatever form the legislation may eventually be drafted, it will have relevance beyond the confines of the telegraph industry or even the whole communications system. The manifold stresses, which now play and for the past decade have played upon what is left of a laissez-faire economy, may result in forcing Congressional reconsideration and progressive abandonment of the simple formula of anti-trust. So far Congress has not found the increasing scope of Government action incompatible with adherence to earlier doctrines articulated when the curse of bigness had first become apparent. Regional monopolies have been preferred to national monopolies and formal competition decreed to mask the competitive void. It is a sign of the times that none of the investigations or hearings of the past ten years

76. Statements of Rear Admiral Hooper and Major General Mauborgne, id. at 61, 64.

77. Statement of FCC Chairman Fly, id. at 13. And see Report of the F.C.C. om the Domestic Telegraph Industry (Dec. 1939), reprinted, id. Pt. II, at 402: "The effect of obsolescence due to changes in the art is the most important depreciation factor with respect to telegraph plant. There is every indication that Western Union has not taken full account of this factor in determining its annual depreciation allowances."

78. See SeN. ReP. on S. Res. 95, 77th Cong., 1st Sess. (1941) 14-15.

79. Postal, as a resuit of its reorganization, now has no long-term secured debt. Western Union has bond issues of over $\$ 80,000,000$ outstanding, of which $\$ 45,000,000$ mature in 1950 and 1951, followed by $\$ 35,000,000$ due in 1960 . The Western Union balance sheet for 1940 showed that over four million dollars was allocated to service on the debt. Neither the FCC report nor the Committee hearings or report consider in any detail the problems which would be raised by security distribution, and the Committee's only recommendation is that the merger legislation provide for the simplest possible financial structure. It was apparently assumed that the financial details of the merger would be worked out by the companies and submitted to a government agency for approval. The problem of excess capacity, uncertain future earnings, Western Union's debt structure, and Postal's continuing deficit will make valuation and agreement on a "fair, equitable and feasible" plan complicated in the extreme. 
has produced the understandable suggestion of a series of interconnected regional communications monopolies - the size and resources of which would not be so great as to defeat effective regulation but which could give efficient service over the areas assigned to them. ${ }^{80}$

Precedents will be few and the problems many if Congress ventures into the field of nationally sponsored monopoly under the supervision of Government agencies. If the ruling consideration is to be the renovation of distressed industries, the continued existence of which is thought essential, so that they may resume profitable operation in private hands, there will have to be a radical modification of some of the "fundamental" concepts of our property law, along with a general atrophy of the concept of due process. Such "guaranteed monopolies" would make necessary the revision of existing patent law, ${ }^{81}$ with the introduction of some form of compulsory crosslicensing system, which, even in the present stage of tentative Presidential suggestion ${ }^{82}$ and desultory committee hearings, ${ }^{83}$ calls forth violent protest. $^{84}$

In the search for precedent Congress will doubtless turn first to past railroad legislation where consolidation has been a word, if not a fact, for twenty years. The Transportation Act of $1920^{55}$ directed the Interstate Commerce Commission to prepare a master plan under which seattered railroad properties could be merged into a few great systems that would be approximately equal in earning power and that might be expected to operate without need of recurrent bankruptcy reorganizations. When a tentative plan was adopted in 1929, the Commission interpreted its mandate to be the drafting of a consolidation plan which would "preserve competition as fully as possible" and set up regional systems which would be independent in fact as well as in name..$^{80}$ The Transportation Act of $1940^{57}$ continues the Commission's authority over unifications, mergers, and acquisitions of control. Pooling or division of traffic, services, or earnings among carriers may be approved by the Commission, on such conditions as the Commission may impose, on a finding that such pooling or division "will be in the interest of better service to the public or of economy in operation, and will not unduly restrain competition." ss Mergers, consolidations, leases, contracts for

S0. This has been the traditional formula applied to industrial trusts. See Fale, Trust Dissolution: "Atomizing" Btısiness Units of Monopolistic Size (1940) $40 \mathrm{CoL}$ L. Rev. 615.

81. See Feuer, The Patent Monopoly and the Anti-Trust Law's (1938) 35 CuL L. REV. 1145.

82. See the President's message suggesting the creation of the Temporary National Economic Committee, 83 Cong. REc. 5995 (1938).

83. See Hearings before the Temporary National Economic Committce, 76th Cong,, 2d Sess. (1939).

84. See, e.g., Toulamn, Patents and tae Public Interest (1939).

85. 41 STAT. 456.

S6. Consolidation of Railroads, 159 I. C. C. $522,523$.

87. 54 Stat. 898.

88. Section 7 of the Act, 54 Stat. 905,49 U. S. C. $\$ 5(2)$ (1940). 
joint operation, or other forms of unified control are also authorized, the Commission's approval being conditioned on a finding that the transaction will be consistent with the public interest. ${ }^{80}$ The Commission is also given authority to require the inclusion of other railroads, should they request it, in a proposed consolidation. On approval by the Commission, and with the assent of the stockholders of the railroads involved, the transaction may be carried into effect, and the corporations and individuals involved relieved from the operation of the anti-trust laws.

It will be apparent that the railroad merger legislation can serve only as a partial guide in the much more comprehensive program proposed for the telegraph merger. In providing for railroad ills Congress has aclopted the formula of strong regional systems and limited competition under strict administrative supervision, in place of the national monopoly under consideration in telegraph and already existing in telephone. Nor has it seemed appropriate to insulate the railroads completely from competing transportation systems - bus, air and water - as contemplated by the TWX and radiotelegraph suggestions advanced in the Committee's report.

Nevertheless, the substantive provisions devised for the railroad consolidations should most certainly be included in the telegraph bill to be introduced. It is of particular importance that the effect of merger upon the quality and cost of service to the public be made one of the prime considerations of administrative review. The reports, hearings, and recommendations have so far been mainly concerned with how to salvage the industry; what the public will get and how much the public will pay for an essential service has received alarmingly little consideration.

Among the most important aspects, perhaps the most important one, of the merger policy is the problem of displaced labor. It is unlikely that conceivable fluctuations of political opinion will sanction operating economies, possible only under Congressional approval, which are achieved through firing surplus workers after unification has taken place. The strength of the labor unions and the high cost of relief preclude this simple and "efficient" solution to a disturbing problem. All parties to the telegraph merger are agreed that the permissive legislation should contain some provision protecting the position of employees; management and labor are understandably in confict on the details of any particular provision. ${ }^{90}$

Since 1930 many factors have forced the development of formulae designed to shift from labor a part of the risk of sudden and unmerited joblessness. Technological displacement and depression dismissals led many firms to

89. Id. $\$ 5(2)$. The Commission is directed to consider, inter alia, (1) the effect of the proposed transaction upon adequate transportation service to the public, (2) the effect upon the public interest of the inclusion, or failure to include, other railroads in the same territory, (3) the total fixed charges resulting from the proposed transaction, (4) the interest of the carrier employees affected.

90. See Hearings (1941) Pt. I, passim. 
adopt some form of dismissal compensation plan, ranging from token payments of one or two weeks' wages to allowance of one or two years' pay.11 Labor sought to obviate the danger of technological change by agreements whereby the employer agreed to retrain at his expense all workers capable of qualifying for the new type of work $;^{92}$ strong unions imposed contracts providing, without qualifications, that no employees were to be dismissed during the life of the agreement because of technological clianges. ${ }^{23}$

Railroad labor history offers the most useful guides to a policy which aims at alleviation of the hardships of merger-unemployment - and in this field the statutory solution was preceded by administrative improvisation and private agreement. In 1936 the railroads and the operating unions negotiated the so-called Washington agreement, which provided a measure of protection for employees dismissed as a result of consolidations. ${ }^{04}$ After the signing of this agreement the Interstate Commerce Conmission, in a case involving a lease of one carrier to another, imposed the requirement that all employees transferred be compensated for any reduction in salary, until they should obtain through seniority new positions at equivalent pay. ${ }^{93}$ The only statutory authorization was the provision in the Interstate Commerce Act that the Commission could approve leases and mergers if they "promote the public interest" and on "just and reasonable" conditions. On appeal the Supreme Court sustained the Commission's action. ${ }^{00}$

The Transportation Act of 1940 has ${ }^{97}$ codified this policy of dealing with loss of employment through consolidation. The Commission is now required to include in its orders of approval:

"terms and conditions providing that during the period of four years from the effective date of such order such transaction will not result in employees of the carrier . . . being in a worse position in the respect to their employment, except that the protection afforded to any employee ... shall not be required to continue for a longer period ... than the period during which such employee was in the employ of such carrier . . . prior to the effective date of such order." 98

91. See Hawhins, Dismissal Compensalion, Mosituly Lazon Revrew (Nov. 1934, April 1935, March 1939, U. S. Dep't Labor).

92. See, c.g., Articies of Agreenent metween the Westers Umo: Teledrapix Company and Local 55-B, Anderican Communicitions Assoctutro:ss (CIO) (1941) $15-16$.

93. See, e.g., Agreement between Ayertcan Cosmiumentions Assoctutio:s (CIO) and Mackay Radio and Telegraph Co. (1941) 13.

94. Reprinted in Hcarings (1941) Pt. II, p. 442 ct seq.

95. Chicago, R. I. \& G. R. R., Trustee's Lease, 230 I. C. C. 181 (1938), rchcaring, 233 I. C. C. 21 (1939).

96. United States v. Lowden, 30 S U. S. 225 (1939).

97. 54 Stat. 898.

98. Section 7 of the Act, 54 Stat. 905, 49 U. S. C. $\$ 5(2)$ (1940). 
This provision goes beyond the usual formula of dismissal pay and provides protection over a much longer period of time than almost all, if not all, private agreements. ${ }^{99}$

It may be that such a provision would not be feasible when applied to an industry like telegraph which has extremely high labor costs and which is already operating close to bankruptcy. On the other hand, personnel studies made by the Communications Commission show that an unusually high proportion of telegraph employees fall in the higher age groups and would under normal conditions have great difficulty in securing equivalent employment. ${ }^{100}$ But it will probably not be found advisable, whether for reasons of politics or economics, to provide that no employee shall for at stated time after the merger be put in a worse condition than before. Thus, a compromise formula providing continued employment for some classes of employees and dismissal pay for others, on a seniority basis, is the indicated solution; a Government agency might well be entrusted with the delicate task of classifying the employees, or else given final authority to approve or reject the results reached by bargaining between labor and management. This problem promises to be a fertile source of discord, but the diffictulties of resolving it will be much less formidable if unification is achieved during the war, since the peak demand will require the continued services of most of those now employed.

The fact of war may lead to an unlooked-for settlement of the industry's troubles. If Congress again resorts to Government operation during the war, the ending may be different from the one contrived in 1919; there are reasons for continuing Government control over an industry which has come to be unprofitable that do not apply — and did not apply to telegraph in 1919 - to an industry with an admirably high rate of earnings, sound financial structure, and, on the surface at least, every prospect of continuing to expand profitably under the stimulus of rapidly increasing demand.

Wisely, peacetime preparation was made for the wartime control of communications. Section 606 of the Communications Act of $1934^{101}$ vested certain powers in the President in time of war: he might under this section give priority and preference to communications essential to the national defense, employ the armed forces to prevent any obstruction or retardation of interstate, or foreign communications by wire or radio, suspend all rules and regulations applicable to carriers under the Act, and close down or control and operate through any Government department any radio station. The just compensation clause contained in the Congressional resolution of

99. Comparable provisions were inserted in the Government Reorganization Act of 1939, 53 Stat. 561.

100. Hearings (1941) Pt. II, p. 280 (tables L-8 and L-9). No definite estimates were made at the hearings as to the number of employees who might be dismissed in the absence of labor protection provisions in the merger legislation.

101. 48 STAT. 1104,47 U. S. C. $\$ 606$ (1940). 
1918 authorizing Government control was re-enacted. The section was passed by Congress as it was introduced, and was not specifically referred to in debates on the Act. Thus, it is not clear why the authority to take control and operate was restricted to radio, while the rest of the section is by its terms applicable to all wire and wireless carriers.

As the international crisis developed, steps were taken to gear the communications system to war economy. An executive order promulgated in September 1940,102 created the Defense Communications Board, with representatives from the FCC, Army, Navy and the Departments of State and Treasury. The Board's function was to prepare plans for the assurance of communications service during a national emergency; censorship was specifically excluded from its jurisdiction. Instead it was directed to study the needs for military communications, the allocation of available facilities between Government and the public, and finally "the measures of control, the agencies to exercise this control, and the principles under which such control will be exercised over non-military communications to meet defense requirements." The Board's actions have not been spread on public record, but the executive mandate was broad enough to permit the formulation of a comprehensive policy of wartime control. With the outbreals of war the Board was ordered to exercise the powers granted the President under Section 606 of the Communications Act. ${ }^{103}$

Further steps were promptly taken by Congress after the declaration on December 8 to give the President the same powers over wire communications which were granted in 1918. A bill, ${ }^{104}$ framed on the joint resolution of 1918, was introduced in the House on December 17th, reported back on the 19th, and, after a brief statement by committee spokesmen, passed without debate and without a record vote. ${ }^{105}$ Two points were made on the House floor: first, that the Bill was not to be construed as a step toward Governmental ownership; second, that passage of the bill had been requested by the Administration only because of "the possible necessity for exercising, as a matter of military expediency, the broad grant of power" conferred, and that there was no present intention to bring communications under Government operation. ${ }^{106}$ A committee amendment introduced in the House limited the duration of the President's authority to a period ending not more than six months after termination of the war. ${ }^{107}$ In the Senate brief discussion reiterated the statements already made in the House. Spokesmen for the bill said that the telephone and telegraph companies, given the oppor$4-5$.

102. Exec. Order No. 8546, 9 U. S. L. Week 2190. Awwunt. Refost FCC (1940)

103. EXec. Order No. 8964 (Dec. 10, 1941), 10 U. S. L. IWEeK 2354.

104. See H. R. 6263, 87 Coxa. Rec., Dec. 17, 1941, at 10209.

105. See id. Dec. 19, 1941, at 10312.

106. See ibid.

107. See id. at 10311. 
tunity to be heard before the Senate Committee on Interstate Commerce, had suggested no amendments to the form in which it had passed the House. ${ }^{108}$ Current plans of the Communications Commission are, according to committee spokesmen, to leave private officials in charge should Government control become necessary. ${ }^{100}$ It was suggested by Senator Taft, although denied by Senator Wheeler, that under the bill the Government would have power to carry out the proposed telegraph merger without further recourse to Congress. ${ }^{110}$ A restrictive amendment, designed to assure continued Congressional control, was rejected, and the bill also passed the Senate without record vote. ${ }^{111}$

The war-time increase of telegraph revenues will not permanently improve the position of the industry; the post-war period will find it in a competitive situation probably less favorable than before. Nor will assurance of communications service through Government control and operation, if followed by reversion to the status quo, be more than a temporary expedient. The power to control and operate seems to imply the power to operate jointly, to effect a consolidation in fact without necessarily observing the legal formalities of consolidation or merger. ${ }^{112}$ Thus, at the end of the war unification of the telegraph companies may be an accomplished fact, through administrative rather than legislative action. The merger legislation, if it is postponed, may then come before Congress as a ratification of an existing situation, and with facts available to indicate the results of unification as to which the Senate Committee could only speculate. But whether merger or some other solution be adopted now or at the end of the war, it is to be hoped that more thorough consideration will be accorded the transaction than has at times been the case in the past. If Congress turns from competition to regulated monopoly in a nationally important field, the implications of the new policy should be understood. The draftsmen of the statute will be creating precedents which will have importance beyond the field of communications.

108. 88 id. Jan. 19, 1942, at 455 .

109. Ibid.

110. Id. at 456 .

111. Id. at 463. The bill was approved by the President on Jan. 26. Id., Jan. 30, at 899.

112. Consider the initiation, under similar statutory authority, of consolidations among telephone companies during the period of federal control in 1918-19, discussed supra page 637. 